\title{
Fraudulence Financial Statements Analysis using Pentagon Fraud Approach
}

\author{
Dedik Nur Triyanto \\ Faculty of Economics and Business \\ Telkom University
}

\begin{abstract}
This study aims to examine the influence of variables, namely pressure, opportunity, rationalization, competence, and arrogance on fraudulent financial statements of companies listed in Indonesia Stock Exchange. The subject of the study is the food and beverage manufacturing firms. The period of investigation is the year $2015-2017$. This study used purposive sampling technique. In total, there are 36 foods and beverage manufacturing firms involved in this study. The data was generated from the firm's annual report using a content analysis approach. Panel data of 36 foods and beverage for three years $(2015-2017)$ was used for analyzing. The analysis model employed in this study is multiple regression. The results indicate that variable namely, pressure, opportunity, rationalization, competence, and arrogance, simultaneously do not affect fraudulence financial statement. Partially, only competence variable significantly affect fraudulence financial statement. It implies that the pentagon theory of fraud is not applicable to understand fraudulence financial statement in the context listed manufacturing firms of food and beverage in Indonesia.
\end{abstract}

Keywords: Fraudulence; Financial statement; Fraud triangle; Pentagon fraud

\section{Introduction}

According to Albrecht and Zimbelman (2009) in Siddiq, Achyani, \& Zulfikar (2017) fraud is an action of a person or individual who can take advantage of other parties by presenting a wrong report. Donald R. Cressey in 1953, introduced the theory of fraud, widely known as the fraud triangle. Next, after the fraud triangle, diamond fraud model was proposed by Wolfe and Hermanson in 2004. The recent theory of fraud introduced by Jonathan Marks in 2012, it refers to the theory of pentagon fraud. The difference between the three theories lies in the factors that influence fraudulent financial statements. The theory of fraud by Wolfe and Hermanson has one factor that influences fraud, and it is namely capability. While the theory of fraud by
Jonathan Marks changed capability factors become competencies and add arrogance factors. Theory pentagon fraud includes five factors, namely, pressure, opportunity, rationalization, competence, and arrogance.

Fraud is an act that violates the existence of concealment, deception, or breach of trust, and this fraudulent action involves other organization to gain personal and business benefits (Aprilia, 2017: 105). Fraud itself is divided into three classifications according to the Association of Certified Fraud Examiners (ACFE), namely corruption, misuse of assets, and fraudulent financial statements. According to Arens et al. (2008), fraudulent financial statements are deliberate misappropriations to make financial report users deceived. ACFE in 2016 also revealed that fraudulent financial statements were the most significant cause of losses in 2016. 
Cases of fraud were found in Indonesia in 2017 involving PT Jatisari Sri Rejeki. The company is cheating by producing rice that is not suitable with standard quality stated in the packaging label. The correlation of the case against fraudulent financial statements is that there is a difference in the inventory account contained in the financial statements due to changes in the quality of products made by the company. Another case revealed in 2014 was a fraud that occurred in PT CocaCola Indonesia (CCI). The company carried out tax evasion activities in 2002, 2003, 2004 and 2006, resulting in a lack of tax payments of Rp.49.24 billion. As a result of the investigation of the Directorate General of Taxes (DGT), the Ministry of Finance found that there were bloated costs due to the high advertising costs from 2002 to 2006 with a total value of $\mathrm{Rp} .566 .84$ billion, which caused PT Coca-Cola's taxable income to decline. From the calculation of taxable income carried out by the DGT towards PT Coca-Cola, the results amounted to $\mathrm{Rp} 603.48$ billion, while the calculation from PT Coca-Cola was only $\mathrm{Rp} 492.59$ billion, giving rise to a difference of $\mathrm{Rp} 49.24$ billion suspected by the DGT is a tax evasion practice that is carried out to minimize taxes (Mustami, 2014). In the case of PT Coca-Cola, it has a relationship to fraudulent financial statements, namely the addition of advertising costs resulting in a small taxable income from the company.

The cases illustrated above indicated that there is a fraud in the food and beverage manufacturing companies. Report findings based on the survey conducted in 2016, shows that fraud in Indonesia manufacturing companies has a low percentage; it is only $3.5 \%$ (ACFE Indonesia Chapter, 2017). However, previous researches conducted in Indonesia that examined fraud using pentagon approach were found consistent in terms of the results. Table 1 shows the results obtained from a sample of listed companies in the food and beverage sector

Table 1. Pressure as function of Financial Statements Fraud

\begin{tabular}{ccc}
\hline Firm & ROA & DAit \\
\hline ICBP & $11.20 \%$ & $0.21 \%$ \\
AISA & $10.63 \%$ & $6.48 \%$ \\
\hline
\end{tabular}

Information stated in Table 1 indicated that pressure as a function of financial statement fraud is proxied by ROA at Indofood companies (ICBP) is $11.20 \%$ and has a fraud rate of $0.21 \%$. Whereas the Tiga Pilar Sejahtera (AISA) company has a smaller ROA of $10.63 \%$, but the level of fraud owned by the Tiga Pilar Sejahtera company is higher than the Indofood companies (ICBP). According to Skousen (2009) in (Siddiq et al., 2017), the financial stability of companies that experience shocks can cause managers to experience pressure, which can lead to fraudulent financial statements. The results from Table 1 support the research conducted by Sukirman \& Pramono Sari (2013) and Aprilia (2017) that the pressure factor has no significant effect on fraudulent financial statements. However, the results inconsistent with the research conducted by Siddiq et al. (2017) and Sihombing, Samuel, \& Rahardjo (2014), which is pressure influences fraudulent financial statements.

Table 2. Opportunities as Function of Financial Statements Fraud

\begin{tabular}{ccc}
\hline Firm & Accounts Receivable Ratio & DAit \\
\hline AISA & $6.41 \%$ & $-3.34 \%$ \\
MYOR & $3.81 \%$ & $6.48 \%$ \\
\hline
\end{tabular}


Table 2 explains that opportunity as a function of financial statement fraud is proxied by the accounts receivable ratio. Tiga Pilar Sejahtera (AISA) company has accounts receivable ratio of $6.41 \%$ and fraud rate of $-3.34 \%$. While Mayora (MYOR) has accounts receivable ratio of $3.81 \%$, but it has a higher fraud rate of $6.48 \%$. Summers (1998) in Yossi \& Handayani (2018) explained that the number of balances from uncollectible accounts and obsolescence is a company policy so that managers will focus on this if they want to commit fraud. The results from Table 2 are supported by research conducted by Akbar (2017) and Tessa \& Harto (2016), which state that opportunities do not affect fraudulent financial statements. However, the results are not consistent with the research conducted by Skousen, Smith, \& Wright (2008), which states that opportunities affect the fraudulent financial statements.

Table 3. Rationalization as Function of Financial Statements Fraud

\begin{tabular}{ccc}
\hline Firm & Change in Auditor & DAit-0.45 \\
\hline STTP & 1 & $-0.45 \%$ \\
ICBP & 0 & $0.21 \%$ \\
\hline
\end{tabular}

Table 3 explains that the rationalization as a function of financial statements fraud is proxied by a change in auditor, where the value of 1 (one) indicates that there was a change in the auditor, while the value of 0 (zero) indicates no auditor changes. In the Siantar Top company (STTP), there have been auditors changes; the value of fraud in Siantar Top company (STTP) is $-0.45 \%$. Whereas in the Indofood Company (ICBP) which did not experience auditor changes, the auditor had a fraud value of $0.21 \%$. Tiffani (2014) in Yossi \&
Handayani (2018) explained that companies that commit fraud would often make auditor changes to eliminate traces of fraud discovered by previous auditors. The summary presented in Table 3 indicates that the results of the study are contrary to the research conducted by Siddiq et al. (2017), which shows that rationalization affects fraudulent financial statements. However, these results are supported by the results of research conducted by Akbar (2017), which states that rationalization does not affect fraudulent financial statements.

Table 4. Competence as function of Financial Statements Fraud

\begin{tabular}{ccc}
\hline Firm & Substitution Directors & DAit \\
\hline AISA & 1 & $-3.34 \%$ \\
ICBP & 0 & $0.21 \%$ \\
\hline
\end{tabular}

Table 4 illustrates that competence as a function of financial statements fraud proxied by the director's changes. The value of 1 (one) indicates that there are directors changes, while the value 0 indicates no directors changes. At Tiga Pilar Sejahtera company (AISA) there are directors changes, but the value of fraud is $-3.34 \%$. Whereas the Indofood company (ICBP), which has not changed the board of directors has a fraud value of $0.21 \%$. According to Tessa \& Harto (2016), the change of directors in a company can lead to a stress period which will open up opportunities for fraudulent financial statements. The results from Table 4 are supported by the research of Annisya, Mafiana, Lindrianasari, \& Asmaranti (2016) which states that competence does not affect fraudulent financial statements, but it is not consistent with the previous researches conducted by Siddiq et al. (2017) and Husmawati (2017) who revealed that competency has an effect on fraudulent financial statements. 
Table 5. Arrogant as function of financial statements fraud

\begin{tabular}{|c|c|c|}
\hline Firms & Total CEO Photos & DAit \\
\hline ICBP & 9 & $0.21 \%$ \\
\hline MYOR & 5 & $6.48 \%$ \\
\hline
\end{tabular}

Table 5 describes the arrogance behavior function of financial statements fraud that is proxied by the total CEO photos on the company's annual report. In Indofood company (ICBP) there are 9 (nine) $\mathrm{CEO}$ photos in the annual report but have a fraud value of $0.21 \%$. Whereas in Mayora's company (MYOR) there were five total CEO photos, but they had a higher fraud score of $6.48 \%$. Tessa \& Harto (2016) explains that the higher the level of arrogance possessed by the CEO, the higher the level of financial report fraud. It is because the CEO will do anything to maintain the position and position that is owned. The results of previous researches presented in Table 5 is inconsistent with the researches conducted by Tessa \& Harto (2016) and Siddiq et al. (2017) which revealed that arrogance has a positive effect on fraudulent financial statements. However, these results are supported by research conducted by Akbar (2017) and which shows that arrogance does not affect fraudulent financial statements.

This study aims to examine whether pentagon model of fraud namely pressure, opportunity, rationalization, competence, and arrogance affect fraudulent financial statements in the food and beverage subsector manufacturing companies listed on the Indonesia Stock Exchange in the period 2015-2017

\section{Literature Review and Hypothesis Development}

\section{Fraud of Financial Reports}

ACFE (2016: 4) mentioned in the 2016 report that there are three main categories of fraud, and fraudulent financial statements are the most significant cause of financial losses in the world. The ACFE statement is supported by Stuart (2012: 149) statement in Syafira (2018), which explains that fraud occurs when the company presents financial statements containing material misstatements. Hery (2017) in Syafira (2018: 14) reveals that there are several techniques for fraudulent financial statements. First, the recording of fictitious journals conducted at the end of the accounting period in order to manipulate the results of the company's operations. Second, the use of inappropriate assumptions and change the balance used in estimating account balances. Third, postpone or acknowledge in advance the recognition of transactions carried out in the current period. Fourth, it does not disclose facts that can affect an amount recorded in the financial statements. Fifth, the use of complex transactions to present the company's financial performance. Sixth, the change records or conditions related to unusual transactions.

\section{Pentagon Fraud and Fraudulence financial statements}

Mark (2012) in Syafira (2018) explains that pentagon fraud, namely pressure, opportunity, rationalization, opportunity, and arrogance, are factors that can influence someone to commit fraud. The results of the study from Siddiq et al. (2017), where the pentagon fraud factors can influence fraudulent financial statements. CEOs who have an ego and confidence in their immunity to company policies can lead to impulses that will lead to fraud when the opportunity arises. 
Rationalization of the fraud that has been done is needed so that other parties do not easily know it, and sufficient competence is needed to be able to condition the situation so that fraud is not suspected (Syafira, 2018). The results of the previous researches are proof that pentagon fraud factors can simultaneously influence the fraudulent financial statements. Therefore, the hypothesis is formulated as follows:

Hypothesis 1: Pressure, opportunity, rationalization, competence, and arrogance simultaneously have a positive effect on fraudulent financial statements.

\section{Pressure and Fraudulence financial statements}

One of the indicators to assess the level of profit is using Return on Asset (ROA). If ROA is high, then management will be more open to fraudulent opportunities. This study was conducted to predict that pressure has a positive effect on fraudulent financial reporting. The basis of references is the previous research results from Setiawati \& Baningrum (2018), Apriyuliana (2017), Akbar (2017), and Nurmulina \& Sasongko (2016) which showed that the pressure on ROA (Return On Asset) proves a positive influence on fraudulent financial reporting. Therefore, the hypothesis is formulated as follows:

Hypothesis 2: Pressure has a positive effect on a fraudulent financial statement.

\section{Opportunities and Fraudulence financial statements}

Uncollectible accounts receivable is one of the accounts in which the company determines account balances based on estimation. Uncollectible accounts are determined based on a subjective assessment in estimating uncollectible accounts. The uncollectible accounts receivable are the main focus of management who will commit fraudulent financial statements. This research was conducted to predict that opportunities have a positive effect on a fraudulent financial statement. The underlying prediction is based on previous research by Yossi Septriani (2018). The study showed that opportunities proxied with firm characteristics proved to have a positive influence on fraudulent financial reporting. Therefore, the hypothesis is formulated as follows:

Hypothesis 3: Opportunities have a positive effect on a fraudulent financial statement.

\section{Rationalization and Fraudulence financial statements}

Change in auditor is a proxy used for rationalization factors. The auditor has the duty to examine and supervise the financial statements made by the management. Companies that commit fraud will often make auditor changes because company management will strive to minimize and eliminate traces of fraud that have been found by the old auditor (Yossi \& Handayani, 2018). This study predicts that rationalization has a positive effect on fraudulent financial statements. This prediction refers to the results of research by Ulfah, Nuraina, \& Wijaya (2017), Siddiq et al. (2017), Nurmulina \& Sasongko (2016), and Husmawati (2017) who stated that accounting with auditor turnover proxies had a positive effect on fraudulent financial statements.

Hypothesis 4: Rationalization has a positive effect on fraudulent financial statements 


\section{Competence and Fraudulence financial statements}

Competency has six components, namely, position, intelligence, confidence, coercion, fraud, and stress management. Competencies that are proxied by the change of directors are considered to be able to describe the competence to carry out stress management. Substitution of directors causes opportunities to commit fraud because there is a stress period that can reduce company performance because the company requires adaptation with the new directors (Tessa \& Harto, 2016). This study predicted that ability has a positive effect on fraudulent financial statements. This prediction refers to the results of the study conducted by Siddiq et al. (2017) and Husmawati (2017) who stated that competencies with proxy directors' proxies proved to have a positive influence on fraudulent financial reporting.

Hypothesis 5: Competence has a positive effect on fraudulent financial statements.

\section{Arrogance and Fraudulence financial statements}

The arrogance factor proxied by the number of CEO photos (Chief Executive Officer) in the company's annual report can show the level of arrogance and superiority possessed by the CEO. Naturally, someone who has a CEO position at the company often wants to show that position. A CEO will do everything he can to maintain his current position, so the number of CEO photos will increase fraud in the company. This study predicted that arrogance has a positive effect on fraudulent financial statements. This prediction refers to the results of the studies conducted by Siddiq et al. (2017), Nurmulina \& Sasongko (2016), Bawekes et al. (2018), and Tessa \& Harto (2016) stating that arrogance with the proxy number of CEO photos proved to have a positive influence on fraudulent financial reporting.

Hypothesis 6: Arrogance has a positive effect on fraudulent financial reporting.

\section{Methodology}

Population in this study is 50 food and beverage manufacturing companies listed in Indonesia Stock Exchange (IDX) for the period 2015-2017. The study used a purposive sampling technique. The criteria used for selecting sample are 1) Food and beverage sub-sector companies listed on the Indonesia Stock Exchange (IDX) for the period 2015-2017; 2) Companies that are consistently listed on the Indonesia Stock Exchange for the period 2015-2017; 3) Having a complete annual report for the period 2015-2017. The summary of the sample selection process is presented in Table 6.

Table 6. Selection sample process

\begin{tabular}{clc}
\hline No & \multicolumn{1}{c}{ Criteria } & Number \\
\hline 1 & $\begin{array}{l}\text { Food and beverage sub-sector companies listed on the Indonesia Stock } \\
\text { Exchange (BEI) from 2015-2017. }\end{array}$ & 50 \\
2 & $\begin{array}{l}\text { Companies that are not consistently listed on the IDX from 2015 to } \\
\text { 2017. }\end{array}$ \\
3 & $\begin{array}{l}\text { Incomplete companies present annual reports and audited finance from } \\
\text { 2015 to 2017. }\end{array}$ \\
\hline
\end{tabular}

Based on table 6, from 2015 to

2017, there were six inconsistent companies listed in the food and beverage sub-sector on the Indonesia Stock 
Exchange because the company experienced delisting. This research requires data from 2015 to 2017 in the form of annual reports to calculate discretionary accruals. Three companies did not meet the criteria for the sample because they did not have a complete annual report. After conducting the process of sample selection based on criteria used in this study, there were 41 food beverages manufacturing companies involved in this study. The study used three years window of investigation (2015 - 2017); therefore, total sample data is 123 ( 3 multiple by 41 companies)

This study used panel data regression analysis. According to Basuki \& Prawoto (2016: 275), panel data regression is a combination of cross-section data and data time series. Independent variables (X) in this study, namely pressure, opportunity, rationalization, competence, and arrogance, while for the dependent variable (Y) in this study is fraudulent financial statements. Panel data regression was formulated as follows; $\mathrm{Y}=\mathrm{a}+\beta 1 \mathrm{X} 1+\beta 2 \mathrm{X} 2+\beta 3 \mathrm{X} 3+$ $\beta 4 \mathrm{X} 4+\beta 5 \mathrm{X} 5+\mathrm{e}$, where:

$\mathrm{Y}=$ dependent variable

$\mathrm{a} \quad=$ Price $\mathrm{Y}$ if $\mathrm{X}=0$

$\beta=$ Regression coefficient

$\mathrm{X} \quad=$ independent variable

e $\quad=$ Error terms

Based on the formula previously determined, the panel data regression used in this study are as follows:
DAit $=\beta 0+\beta 1$ ROA $+\beta 2$ RECEIVABLE + $\beta 3 \triangle \mathrm{CPA}+\beta 4 \mathrm{DCHANGE}+\beta 5$ CEOPIC + e, Where:

$\beta 0=$ Regression coefficient constant

$\beta 1,2,3,4,5=$ Regression coefficient of each proxy

DAit = Discretionary accruals on company $i$ in period $t$

$\begin{array}{ll}\text { ROA } & =\text { Return on Asset } \\ \text { RECEIV } & =\text { Change of debt ratio } \\ \triangle \text { CPA } & =\text { Independent auditor } \\ \text { change } & \\ \text { DCHANGE } & =\text { Change of directors } \\ \text { CEOPIC } & =\text { Number of CEO photos } \\ \mathrm{e} & =\text { Error term }\end{array}$

\section{Results and Discussion}

Statistical descriptive aims to explain descriptively the dependent variable and the independent variables used in the study. The results of the statistical descriptive are presented in Table 7. Based on the information presented in Table 7 , the dependent variable, namely DAit has an average value of -0.295652 . The average value is smaller than the standard deviation value that is equal to 0.735118 . The maximum DAit value is 0.064810 , and the DAit minimum value is -2.749350 . The ROA variable has a maximum value of 52.67. The minimum value of ROA is -9.71 and has an average value of 10.60306, where the average value is smaller than the standard deviation value of 11,80011 .

Table 7. Descriptive Statistics

\begin{tabular}{lcccc}
\hline & DAit & ROA & NOI & CEOPIC \\
\hline Mean & 10.60306 & 0.848056 & 3.111111 & -0.295652 \\
Median & 8.495000 & 0.315000 & 3.000000 & -0.003375 \\
Maximum & 52.67000 & 8.010000 & 7.000000 & 0.064810 \\
Minimum & -2.749350 & -9.710000 & -5.000000 & 0.000000 \\
Std. Dev. & 0.735118 & 11.80010 & 2.542917 & 1.848208 \\
\hline
\end{tabular}

The NOI variable has an average value of 0.848056 , where the average value is smaller than the standard deviation value that is equal to 2.542917 . The maximum value owned by the NOI variable is 8.01 , while the minimum value of the NOI variable is -5.0. The CEOPIC variable has an average value of 3.111111 , where the average value is higher than the standard deviation value of 1.848208 . The maximum 
value in the CEOPIC variable is 7.0, while the CEOPIC variable minimum value is 0.0 .

Table 8. Descriptive Statistics Nominal Scale

\begin{tabular}{lllcc}
\hline Variable & Criteria & \multicolumn{2}{c}{$\begin{array}{c}\text { Total } \\
\text { Sample }\end{array}$} & \multirow{2}{*}{ TOTAL } \\
\cline { 1 - 3 } CIA (Auditors Changes) & Auditors substitution & 7 & $19.44 \%$ & 36 \\
\cline { 2 - 4 } & No auditor substitution & 29 & $80.56 \%$ & $(100 \%)$ \\
\hline \multirow{3}{*}{$\begin{array}{l}\text { DCHANGE (Directors } \\
\text { Changes }\end{array}$} & Substitution Board of Directors & 11 & $30.56 \%$ & 36 \\
\cline { 2 - 3 } & No Substitution of Directors & 25 & $69.44 \%$ & \\
\hline
\end{tabular}

Table 8 shows the results of descriptive statistical tests on a nominal scale. CIA variables show that out of 36 existing samples, there are 7 or $19.44 \%$ who make external auditor changes. Meanwhile, the remaining, as many as 29 or $80.56 \%$ did not make changes to external auditors. The DCHANGE variable shows that out of 36 existing samples, there were 11 or $30.56 \%$ who made changes to directors. Meanwhile, the remaining, 25 or $69.44 \%$ did not make changes to directors.

Based on the model estimation test, it was found that the model fixed effect most appropriate was used in this study. Information presented in Table 9 are the results of testing using the model fixed effect. Based on table 9, the test results of the pressure variable show that ROA (Return on Assets) does not affect fraudulent financial statements, it is indicated by a probability value of 0.1476 which is above a significance value of 0.05 or $5 \%$. The coefficient value of the pressure variable is -7.844167 , which indicates that the pressure variable has a negative direction towards fraudulent financial statements. The results of the study that show that financial target (ROA) does not affect fraudulent financial reporting is because the company, in this case, the financial manager assumes that the ROA target is not difficult to achieve and considers the value is still reasonable so that the ROA target does not trigger financial report fraud.

Table 9. Test Results for Fixed Effect Models

\begin{tabular}{ccccc}
\hline Variable & Coefficient & Std. Error & t-Statistic & Prob. \\
\hline X1 & -0.004521 & 0.002995 & -1.509573 & 0.1476 \\
X2 & 0.013696 & 0.007396 & 1.851890 & 0.0796 \\
X3 & -0.053655 & 0.037625 & -1.426017 & 0.1701 \\
X4 & -0.067537 & 0.028881 & -2.338426 & 0.0305 \\
X5 & 0.012799 & 0.013564 & 0.943620 & 0.3572 \\
$C$ & -0.268076 & 0.050366 & -5.322566 & 0.0000 \\
\hline
\end{tabular}

Based on information in Table 9, the results of the study show that NOI (Nature of Industry) does not affect fraudulent financial statements, it is indicated by the probability value of 0.0796 which is above a significance value of 0.05 or $5 \%$. The coefficient value of the opportunity variable is 0.013696, which indicates that the opportunity variable has a positive direction towards fraudulent financial statements. These results occur because the size of the ratio of changes in accounts receivable during the year of observation did not trigger management to commit fraud. In addition, differences in the nature of the industry in banking companies with other sectors make the value of trade accounts 
receivable not be used to detect fraudulent actions committed by management.

The results of testing of the rationalization variable show that CIA (Change in Auditor) does not affect fraudulent financial statements, it is indicated by a probability value of 0.1701 which is above a significance value of 0.05 or $5 \%$. The coefficient value of the rationalization variable is - 0.053655 , which indicates that the rationalization variable has a negative direction towards fraudulent financial statements. Auditor changes made by public companies are not because they want to erase traces of fraud found by auditors before, but because companies obey Government Regulation Number 20 of 2015 concerning Practices of Public Accountants article 11 paragraph 1.

Test results from competency variable show that DCHANGE (Directors Change) affects fraudulent financial statements; this is indicated by the probability value of 0.0305 , which is below the significance value of 0.05 or $5 \%$. The coefficient value of the competency variable is -0.067537 which indicates that the competency variable has a negative direction towards fraudulent financial statements, a negative sign on the coefficient value indicates an inverse relationship between the competency variable to fraudulent financial statements. The results of these tests indicate that competency influences fraudulent financial statements occurs because companies make changes to directors to cover up fraud that has been done by previous directors. The new Directors need time to adapt to the company's financial information. So, with the change of directors, it would be a little difficult to detect fraud committed by the previous directors.

The test results of arrogance variables show that CEOPIC does not affect fraudulent financial statements; it is indicated by the probability value of 0.3572 , which is above the significance value of 0.05 or $5 \%$. The coefficient value of the arrogance variable is 0.012799 , which indicates that the arrogance variable has a positive direction towards fraudulent financial statements. If the number of CEOs of the company increases, the more ideas there are for the company, if the ideas are mutually beneficial to each other in general benefit the company, then fraud in the preparation of the company's financial statements can be avoided.

The result of the model test, as presented in Table 9, shows that together, variable namely pressure, opportunity, rationalization, competence, and arrogance do not affect fraudulence financial statement. It was indicated with Adjusted $\mathrm{R}$-squared $\left(\mathrm{X}^{2)}\right.$ value equal to 0.993254 , which is above the $p$-Value (0.05).

Table 9. Cross-Section Test

\begin{tabular}{lc}
\multicolumn{1}{c}{ Statistic } & Value \\
\hline R-squared & 0.996338 \\
Adjusted R-squared & 0.993254 \\
SE of regression & 0.060380 \\
Sum squared residual & 0.069270 \\
Log-likelihood & 61.47705 \\
Mean dependent var & -0.295652 \\
SD dependent var & 0.735118 \\
Akaike info criterion & -2.470947 \\
Schwarz criterion & -1.723175 \\
Hannan-Quinn criteria. & -2.209955 \\
Durbin-Watson stat & $3,928,108$ \\
F-statistic & 323.0576 \\
Prob (F-statistic) & 0.000000 \\
\hline
\end{tabular}




\section{Conclusion}

Based on the results of the simultaneous test, the conclusions that can be drawn from the results of the test are that pressure, opportunity, rationalization, competence, and arrogance do not affect fraudulent financial statements in the food and beverage sub-sector manufacturing companies listed on the Indonesia Stock Exchange 2015-2017. Based on the results of the partial test, the conclusions that can be taken are the pressures that are proxied by Return on Assets, Opportunities proxied by Nature Of Industry, Rationalizations proxied by Change in Auditors, and Arrogances proxied by CEOPIC do not affect fraudulent financial statements whereas Competencies proxied by Directors Change affect fraudulent financial statements with negative direction.

Researchers have difficulty in finding coefficients for calculating financial report fraud variables due to short periods of investigation. It is recommended for future researchers to add to the research period so that they can avoid the problem of calculating coefficients on financial report fraud variables. The results of the study are expected to give a contribution to understanding the potential factors of fraud. Therefore, the function of financial statements as a source of information for users can be used better decision making.

\section{References}

ACFE. (2016). Accounting Concepts: Financial Transactions and Fraud Schemes.

Akbar, T. (2017). The Determination of Fraudulent Financial Reporting Causes by Using Pentagon Theory On Manufacturing Companies In Indonesia. International Journal of Business, Economics and Law, 14(December), 106-113.
Annisya, Mafiana, Lindrianasari, \& Asmaranti. (2016). Pendeteksian Kecurangan Laporan Keuangan Menggunakan Fraud Diamond. Jurnal Bisnis Dan Ekonomi, 23(1), 72-89. Aprilia. (2017). Analisis Pengaruh Fraud Pentagon Terhadap Kecurangan Laporan Keuangan Menggunakan Beneish Model Pada Perusahaan Yang Menerapkan Asean Corporate Governance Scorecard, 9(1), 101-132. Apriyuliana, A. (2017). Mendeteksi Fraudulent Financial Reporting Dengan Analisis Faktor Risiko Kecurangan Teori Fraud Pentagon.

Basuki, AT, \& Prawoto, N. (2016). Analisis Regresi Dalam Penelitian Ekonomi \& Bisnis: Dilengkapi Aplikasi SPSS \& EViews. Depok: Rajagrafindo Persada.

Bawekes, HF, Simanjuntak, AMA, \& Daat, SC (2018). Pengujian Teori Fraud Pentagon Terhadap Fraudulent Financial Reporting. Jurnal Akuntansi \& Keuangan Daerah, 13(1), 114-134.

Djiwandono, PI (2015). Meneliti itu Tidak Sulit: Metodologi Penelitian Sosial dan Pendidikan Bahasa.

Husmawati, P. (2017). Analisis Fraud Pentagon Dalam Analisis Fraud Pentagon Dalam Mendeteksi Kecurangan Laporan Keuangan.

Movanita, ANK (2017). Kasus Kecurangan Produksi Beras PT Jatisari Segera Masuk Persidangan.

Mustami, AA (2014). Coca-Cola Diduga Akali Setoran Pajak.

Neolaka, A. (2014). Metode Penelitian dan Statistik. Bandung: Rosda Karya.

Noor, J. (2017). Metodologi Penelitian: Skripsi, Tesis, Disertasi, dan Karya Ilmiah.

Nurmulina, A., \& Sasongko, N. (2018). Analisis Fraud Pentagon Dalam Mendeteksi Financial Statement Fraud.

Setiawati, E., \& Baningrum, RM (2018). Deteksi Fraudulent Financial Reporting Menggunakan Analisis Fraud Pentagon : Studi Kasus pada 
Perusahaan Manufaktur yang Listed di BEI Tahun 2014-2016. Riset Akuntansi Dan Keuangan Indonesia, 3(1953), 91-106.

Siddiq, FR, Achyani, F., \& Zulfikar. (2017). Fraud Pentagon dalam Mendeteksi Financial Statement Fraud. Prosiding Seminar Nasional Dan The 4th Call for Syariah Paper, 114.

Sihombing, Samuel, K., \& Rahardjo, SN (2014). Analisis Fraud Diamond dalam Mendeteksi Financial Statement Fraud: Studi Empiris pada Perusahaan Manufaktur yang Terdaftar di Bursa Efek Indonesia (BEI) Tahun 2010-2012. Diponegoro Journal of Accounting, 3, 1-12.

Siyoto, S., \& Ali, S. (2015). Dasar Metodologi Penelitian.

Skousen, CJ, Smith, KR, \& Wright, CJ (2008). Detecting and Predicting Financial Statement Fraud: The Effectiveness od The Fraud Triangel and SAS No.99., 13.

Stuart, IC (2012). Auditing and Assurance Services.

Sukirman, \& Pramono Sari, M. (2013). Model Deteksi Kecurangan Berbasis Fraud Triangle. Jurnal Akuntansi \& Auditing, 9.

Syafira, NF (2018). Analisis Kecurangan Pelaporan Keuangan Dalam Perspektif Fraud Pentagon (Studi pada Perusahaan Manufaktur Sektor Industri Dasar dan Kimia Periode 2012-2016), (2).

Tessa, C., \& Harto, P. (2016). Fraudulent Financial Reporting: Pengujian Teori Fraud Pentagon Pada Sektor Keuangan Dan Perbankan Di Indonesia. Simposium Nasional Akuntansi XIX.

Ulfah, M., Nuraina, E., \& Wijaya, AL (2017). Pengaruh Fraud Pentagon Dalam Mendeteksi Fraudulent Financial Reporting (Studi Empiris Pada Perbankan di Indonesia yang Terdaftar di BEI pada Tahun 2011-
2015). Forum Ilmiah Pendidikan Akuntansi, 5(1), 399-417.

Yossi, S., \& Handayani, D. (2018). Mendeteksi Kecurangan Laporan Keuangan dengan Analisis Fraud Pentagon ., 11(1), 11-23. 